KS. JAROSŁAW R. MARCZEWSKI* - LUBLIN

\title{
HERI ET HODIE. \\ CHEŁMSKIE AKTA BISKUPIE I KONSYSTORSKIE WEDLUG SPISU ZDAWCZO-ODBIORCZEGO Z 1743 ROKU A OBECNY STAN ICH ZACHOWANIA W ARCHIWUM ARCHIDIECEZJALNYM LUBELSKIM
}

Frapującym tematem dla badaczy archiwów kościelnych jest stosunek pomiędzy zgromadzonym w nich zasobem a liczbą i rodzajem wytworów aktotwórczej działalności danej instytucji, przekazywanych do archiwum. Okazję do podjęcia tego rodzaju szczegółowych dociekań w zakresie doby staropolskiej dają często inwentarze archiwalne oraz spisy ksiąg i dokumentów sporządzane z racji dokonywanych wizytacji biskupich. Ciekawsze od nich są wszakże protokoły zdawczo-odbiorcze, sporządzane w związku z przekazywaniem materiałów tracących związek z bieżącą działalnością danego urzędu do miejsca ich wieczystego przechowywania. O ile współcześnie spisy tego rodzaju są standardem archiwalnym, o tyle zachowały się one stosunkowo rzadko w odniesieniu do dawnych epok. Stąd też dotarcie do tego rodzaju spisu, dotąd nieznanego lub nieopracowanego, może stanowić ciekawostkę badawczą. W niniejszym tekście została ona rozwinięta $\mathrm{w}$ formie artykułu o pewnych fragmentach spuścizny dawnej łacińskiej diecezji chełmskiej, które znalazły się w zasobach Archiwum Archidiecezjalnego Lubelskiego.

\section{Archiwum biskupie i konsystorskie a chelmska kapituła katedralna}

Na specyfikę istniejącej niegdyśs chełmskiej diecezji obrządkułacińskiego w ciągu całych jej dziejów składało się etniczne i wyznaniowe, a potem także obrządkowe zróżnicowanie ludności zamieszkującej jej terytorium. Zdecydowana przewaga żywiołu ruskiego - prawosławnego, a potem katolickiego, ale wschodniego obrządku - stanowiła tu dziejową dominantę. Po części konsekwencją tego stanu rzeczy było strukturalne zapóźnienie i materialny niedostatek kościelnych insty-

* Ks. Jarosław Roman Marczewski - dr hab. historii Kościoła, adiunkt w Instytucie Historii Kościoła i Patrologii, Wydział Teologii KUL, e-mail: jmarcz@kul.lublin.pl 
tucji łacińskich ${ }^{1}$. Dodatkowym czynnikiem wpływającym na stan diecezji było jej położenie w zasięgu tatarskich inkursji².

W przedstawionych okolicznościach urząd biskupi nie znajdował stałego oparcia w rezydencji stołecznej, której przez długi czas po prostu nie było. Również rezydencja zasadnicza poszczególnych biskupów chełmskich zmieniała wielokrotnie swą lokalizację. W rezultacie, wytwory kancelarii urzędu biskupiego były często przenoszone, co stanowiło poważne niebezpieczeństwo dla ich integralności. Nic zatem dziwnego, że przynajmniej od XVII w. chełmskie acta episcopalia, prowadzone zresztą w postaci jednej serii ksiąg, zamiast do archiwum biskupiego trafiały - przynajmniej okresowo - pod opiekę kapituły katedralnej³

Charakterystyczne dla aktywności kapituły chełmskiej było to, że pod jej kuratelę trafiały także akta konsystorza chełmskiego. Wiązało się to zapewne z przekonaniem o lepszym zabezpieczeniu archiwum konsystorskiego przez kapitułę, będącą ciałem o charakterze korporacyjnym, a więc odznaczającym się ciągłością instytucjonalną. Niewykluczone, że archiwum kapitulne dysponowało po prostu także lepszym pomieszczeniem niż lokum konsystorza, co w sytuacji stałego zagrożenia tatarskiego, a potem również długotrwałych wojen prowadzonych przez Rzeczpospolitą nie było bez znaczenia. Ponadto chełmskimi oficjałami generalnymi bywali z reguły kanonicy katedralni. Zresztą tak konsystorz jak i kapituła miały swoją siedzibę w Krasnymstawie, gdzie znajdowała się od końca XV w. stolica diecezji chełmskiej ${ }^{4}$.

Miejscem, w którym usytuowane było archiwum kapitulne, a w konsekwencji także archiwum biskupie i konsystorskie była katedra pw. Rozesłania św. Apostołów w Krasnymstawie. Pomieszczenie archiwum znajdowało się w świątyni nad zakrystią ${ }^{5}$.

Opiekunem archiwum z ramienia kanonickiego gremium był urzędnik pełniący funkcję kanclerza kapituły. Gdy około połowy XVII w. powołana została w kapitule chełmskiej godność prałata kanclerza, wówczas faktyczne spełnianie roli opiekuna archiwum - przy zachowaniu formalnej odpowiedzialności kanclerza spadło na rezydujących częściej bądź stale przy katedrze urzędników i pomocników kapitulnych w postaci prokuratora kapituły lub jej wicekustosza. Stan taki

${ }^{1}$ T.M. Trajdos, Kościół katolicki na ziemiach ruskich Korony i Litwy za panowania Władysława II Jagietly (1386-1434), t. II [mps własność Autora], s. 378-534; A. Gil, Prawosławna eparchia chetmska do 1596 roku, Lublin-Chełm 1999, s. 65-191; tenże, Chetmska diecezja unicka 1596-1810. Dzieje i organizacja, Lublin 2005, s. 133-169.

${ }^{2}$ M. Horn, Chronologia i zasięg najazdów tatarskich na ziemie Rzeczypospolitej Polskiej w latach 1600-1647, „Studia i Materiały do Historii Wojskowości”, 8 (1962) cz. 1, s. 3-71; tenże, Skutki ekonomiczne najazdów tatarskich z lat 1605-1633 na Ruś Czerwona, Wrocław-Warszawa-Kraków 1964; A. Rybak, Dzieje ziemi chetmskiej. Kalendarium, Chełm 1998, s. 34-36.

${ }^{3}$ Nie było to zjawisko odosobnione na gruncie kościelnym w okresie staropolskim; H.E. Wyczawski, Polskie archiwa kościelne, w: Księga tysiaclecia katolicyzmu w Polsce, red. M. Rechowicz i in., cz. 2: Kościót a nauka i sztuka, Lublin 1969, s. 67.

${ }^{4}$ J.R. Marczewski, Dzieje chetmskiej kapituły katedralnej obrzadku łacińskiego, Lublin 2013, s. 539-541, 543-544.

${ }^{5}$ Tamże, s. 544. 
trwał do drugiej połowy kolejnego stulecia, kiedy to ustanowiono w kapitule najpierw archiwariusza, a potem sekretarza, któremu formalnie zlecono troskę o archiwum ${ }^{6}$.

Z akt czynności kapituły chełmskiej wynika jednoznacznie, że podejmowała ona w ciągu dziejów liczne działania mające na celu zabezpieczenie wytworów aktotwórczej działalności kancelarii biskupiej i konsystorskiej. Przykładowym efektem tego rodzaju starań, zgodnych zresztą nie tylko z postanowieniami kapituły, ale również biskupa, była przeprowadzona w $1743 \mathrm{r}$. akcja przeniesienia tychże materiałów do archiwum kapitulnego w kościele katedralnym7.

\section{Zawartość archiwum konsystorza w 1743 roku}

Przy okazji przekazywania materiałów archiwalnych został spisany przez notariusza konsystorza i zarazem członka chełmskiej kapituły katedralnej, kanonika Józefa Ludwika Balickiego, regestr akt przyjmowanych do archiwum. Jako że archiwalia przenoszono z konsystorza, całość zyskała miano akt konsystorskich, pomimo że znajdowały się pomiędzy nimi również akta biskupie. Ze wstępnej uwagi poczynionej do tego wykazu wynikało, że wymienione materiały archiwalne stanowiły komplet dokumentów, jakimi dysponował wówczas konsystorz. Potwierdził to, konfrontując treść regestru ze stanem faktycznym, rezydujący wówczas przy katedrze kanonik Adam Drzewiecki, który odebrał materiały w imieniu kapituły $^{8}$. Na stan zbioru składały się odnotowane przez kanonika Balickiego sposobem numerycznym następujące księgi i luźne papiery ${ }^{9}$ :

1. Acta Illustrissimi Georgii Zamoyski episcopi Chelmensis ab anno 1601 a die 13 iunii.

2. Acta iudiciaria eiusdem Illustrissimi Zamoyski a die 16 februarii anni 1614 ad diem 6 decembris anni 1620. W tejże księdze jest książka aktów Illustrissimi Remigii Koniecpolski episcopi Chelmensis a die 22 septembris anni 1628 ad diem 21 maii anni 1633.

3. Acta visitationum Illustrissimi Zamoyski episcopi Chelmensis ab anno Domini 1602 ad 1605. W tejże księdze są acta visitationum Illustrissimi Koniecpolski ab anno 1629.

4. Acta iudiciaria Illustrissimi Domini Mathiae Łubieński episcopi Chelmensis a die 9 decembris anni 1621 ad diem 25 septembris anni 1626.

5. Acta visitationum eiusdem Illustrissimi Łubieński episcopi Chelmensis a die 20 februarii anni 1622 ad diem 8 ianuarii anni 1623.

${ }^{6}$ Tamże, s. 89, 109, 114-117, 542-543, 548-549.

${ }^{7}$ Tamże, s. 546.

${ }^{8}$ Archiwum Archidiecezjalne Lubelskie (dalej: AAL), Rep 64 A 4, k. 323v.

${ }^{9}$ Przytoczony został tu oryginalny tekst regestru w zakresie specyfikacji archiwaliów. Pominięte zostały bardziej szczegółowe opisy woluminów, zwłaszcza zaś to co dotyczyło zewnętrznej strony zjawisk archiwalnych, do których odniesienia znajdują się w dalszej części niniejszego artykułu. W przytoczonym tekście w nawiasach kwadratowych zaznaczono opustki umyślne, które niekiedy udało się uzupełnić w oparciu o analizę zawartości zachowanych ksiąg; AAL, Rep 64 A 4, k. $321 \mathrm{r}-323 \mathrm{v}$. 
6. Acta iudiciaria Reverendissimi Domini Joannis Abrahami Śladkowski suffraganei et officialis Chelmensis a die 9 augusti 1627 ad diem 17 martii anni 1641.

7. Acta iudiciaria Perillustris Joannis Sasin canonici cathedralis et surrogati Chelmensis, praepositi Skierbieszowiensis sub Illustrissimo Koniecpolski episcopo Chelmensi a die 25 augusti anni 1629 ad diem 17 novembris anni 1631.

8. Acta iudiciaria eiusdem Perillustris Sasin canonici et officialis Chelmensis a die 3 ianuarii anni 1632 ad diem 12 octobris anni 1640.

9. Acta iudiciaria Reverendissimi Joannis Śladkowski suffraganei et administratoris generalis a die 23 martii anni 1641 ad diem 3 octobris anni eiusdem. W tejże księdze są acta iudiciaria Reverendissimi Nicolai Świrski suffraganei et officialis Chelmensis a die 18 ianuarii anni 1651 ad diem 8 martii anni 1652. W tejże księdze są acta iudiciaria Perillustris Francisci Malinowski canonici et iudicis surrogati Chelmensis, praepositi Skierbieszowiensis a die 21 octobris anni 1653 ad diem 30 novembris anni eiusdem.

10. Acta visitationum Perillustris Sasin canonici et officialis Chelmensis sub Illustrissimo Koniecpolski episcopo Chelmensi a die 10 septembris anni 16[35] ad diem 12 ianuarii anni 1638.

11. Acta iudiciaria Illustrissimi Domini Pauli Piasecki episcopi Chelmensis a die 12 martii anni 1642 ad diem 13 februarii anni 1645. W tejże księdze są akta sądowe Illustrissimi Domini Stanislai Pstrokoński a die 23 februarii anni 1645 ad diem 17 martii anni 1655.

12. Acta iudiciaria Reverendissimi Nicolai Świrski suffraganei et officialis Chelmensis a die 27 maii anni 1646 ad diem [8] februarii anni 1651.

13. Acta iudiciaria Perillustris Kłopocki decani infulati et officialis foranei Zamostiensis a die 30 octobris anni 1663 ad diem 8 ianuarii anni 1666.

14. Acta iudiciaria Illustrissimi Domini Christophori Żegocki episcopi Chelmensis ab anno inchoative 1671 ad annum 1672. W tejże księdze są acta visitationum eiusdem Illustrissimi Żegocki.

15. Protokół aktów sądowych sub Illustrissimo Stanislao Święcicki episcopo Chelmensi sub officialatu Perillustris Francisci Wybranowski ab anno 1685 ad 1687 mensem iunium pisany ręką Wielmożnego Jegomości Księdza Walentego Czulskiego natenczas pisarza konsystorskiego.

16. Acta iudiciaria Illustrissimi Domini Stanislai Święcicki episcopi Chelmensis ab anno 1685 a die 28 iunii ad annum 1691 ad diem [9] decembris.

17. Protokół aktów sądowych eiusdem Illustrissimi Domini Święcicki episcopi pisany ręką Jegomości Księdza Piotra Garbowskiego natenczas pisarza a die 14 novembris anni 1691 ad diem 10 octobris anni 1696.

18. Protokół aktów sądowych Reverendissimi Joannis Dłużewski suffraganei et administratoris Chelmensis a die 19 decembris anni 1696 ad diem 3 iulii anni 1699.

19. Protokół aktów sądowych Perillustris Pauli Chotecki archidiaconi et administratoris Chelmensis a die 26 augusti anni 1705 ad diem 17 martii anni 1713.

20. Protokół aktów sądowych sub officialatu Perillustris Valentini Czulski archidiaconi Chelmensis et Perillustris Petri Garbowski cancellarii et iudicis surro- 
gati Chelmensis a die 23 martii anni 1713. W tejże tece jest protokół aktów sądowych Illustrissimi Domini Christophori Szembek episcopi Chelmensis a die 27 augusti anni 1714 ad diem 9 iunii anni 1719.

21. Volumen primum maius actorum visitationis et iurium ecclesiarum dioecesis Chelmensis sub Illustrissimo Domino Christophoro Szembek episcopo Chelmensi, quod volumen incipit a litteris innotescentialibus pro hac visitatione die 18 martii anno 1714 editis et terminatur in decreto reformationis pro ecclesia parrochiali Chłaniowiensi.

22. Volumen secundum minus visitationum eiusdem Illustrissimi Domini Christophori Szembek episcopi Chelmensis, quod volumen incipit a brevi Clementis XI papae ad clerum et populum totius dioecesis Chelmensis, quo brevi idem Illustrissimus est confirmatus episcopus Chelmensis et terminatur hoc volumen in processu innotescentialium pro coronatione miraculosae imaginis Częstochowiensis Beatae Virginis Mariae anno Domini 1718 die 25 iulii edito.

23. Protokół aktów sądowych Illustrissimi Domini Alexandri Fredro episcopi Chelmensis a die 19 iunii anni 1719 ad diem 10 ianuarii anni 1724.

24. Protokół aktów sądowych sub Perillustri Valentino Czulski archidiacono et officiali Chelmensi tylko jeden arkusz sub die 8 martii anni 1719, a zaś cała księga zaczyna się a die 19 februarii anni 1721 ad diem 7 novembris anni 1724. W tejże książce są akta sub Illustrissimo Domino Fredro episcopo Chelmensi a die 5 maii anni 1724 ad diem 9 martii anni 1725. Tamże są akta Illustrissimi Domini Joannis Szaniawski a die 11 aprilis anni 1725 ad diem 24 ianuarii anni 1726.

25. Acta iudiciaria Illustrissimi Domini Joannis Szaniawski episcopi Chelmensis a die 24 aprilis anni 1725 ad diem 17 decembris anni 1727 sub notariatu Illustris Admodum Reverendi Valentini Wróblowski canonici titularis Chelmensis.

26. Protokół aktów sądowych eiusdem Illustrissimi Domini Szaniawski episcopi a die 24 aprilis anni 1725 ad diem 17 februarii anni 1731 sub notariatu eiusdem Illustris Wróblowski canonici titularis et Domini Petri Mąkowski laici.

27. Acta iudiciaria eiusdem Illustrissimi Domini Szaniawski episcopi Chelmensis anni inchoative 1731 et sequentes sub notariatu Perillustris Balicki canonici Chelmensis.

28. Metrica confirmatorum hominum ab eodem Illustrissimo Domino Szaniawski.

29. Protokół tychże aktów Illustrissimi Domini Szaniawski episcopi sub eodem notario Perillustri Balicki a die 14 martii anni 1731 ad diem 14 decembris anni 1733, qui utinam hucusque viveret ad eius clientium solatium.

30. Acta visitationum eiusdem Illustrissimi Domini Szaniawski episcopi a die 28 maii anni 1726 a visitatione ecclesiae parrochialis Mostowiensis ad diem 11 novembris anni 1729 ad visitationem ecclesiae Starozamostiensis inclusive.

31. Akta i protokoły sądowe sede vacante episcopatus Chelmensis sub Perillustri Domino Valentino Chlebowski administratore et sub Perillustri Domino Laurentio Czulski cancellario et officiali a die [8] ianuarii anni $1734 \mathrm{ad}$ diem [...] 
martii anni 1736 ad fata eiusdem Perillustris Domini Chlebowski. Item sub Perillustri Domino Alexandro Grzymała custode et administratore a die [...] maii 1736 ad diem [...] martii anni 1737.

32. Akta i protokoły sądowe Illustrissimi Domini Josephi Eustachii Szembek episcopi Chelmensis a die [...] martii anni 1737 ad annum 1738 sub notariatu eiusdem Perillustris Balicki canonici.

33. Wizyty kościołów niektórych eiusdem Illustrissimi Domini Josephi Szembek episcopi Chelmensis.

34. Producta id est variae citationes et varia munimenta a partibus secum iure certantibus iudicialiter reposita totius anni 1731 et 1732 et 1733 consequenter usque ad annum 1738 inclusive in suis fasciculis bene ligatis existentia.

35. Producta iudicialia i różne papiery prawne et varia miscellamina anni 1696 $\mathrm{i}$ innych różnych lat także w snopeczki powiązane.

\section{Stan aktualny spuścizny konsystorza chełmskiego}

Analiza zawartości archiwum przechowującego w połowie XVIII w. księgi konsystorza chełmskiego, dokonana w oparciu o wspomniany inwentarz prowadzi w sposób naturalny do pytania o aktualny stan zachowania wskazanych archiwaliów. Czy i w jakim zakresie znajdują się one w zasobach Archiwum Archidiecezjalnego Lubelskiego?

Dwie pierwsze księgi wymienione w inwentarzu kanonika Balickiego to akta czynności biskupich Jerzego Zamoyskiego, który sprawował posługę biskupa chełmskiego w latach 1601-1621. Pierwsza $\mathrm{z}$ ksiąg oznaczona jest obecnie sygnaturą Rep 60 A 106 i zgodnie z informacją z regestru kanonika Balickiego rozpoczyna się od wpisu z 13 czerwca 1601 r. Ostatni wpis datowany został 8 marca 1613 r. Na końcu księgi znajduje się spis jej zawartości wykonany w 1734 r. przez kanonika Balickiego. Tymczasem druga z ksiąg, oznaczona sygnaturą Rep 60 A 107, spisywana od 16 lutego 1614 r., kończy się informacją o śmierci bpa Zamoyskiego 4 stycznia $1621 \mathrm{r}$. Również do tej księgi został dołączony wykaz jej zawartości autorstwa kanonika Balickiego. Należy jednak zauważyć, że inaczej niż podaje to regestr z 1743 r., nie ma w niej aktów czynności biskupich Remigiusza Koniecpolskiego, biskupa chełmskiego w latach 1627-1640. Akta te nie były jednak wszyte w księgę, ale po prostu do niej dołączone w postaci wkładki. Księga ta musiała zatem zostać zdekomponowana. Tekst z $1743 \mathrm{r}$. informuje ponadto o tym, iż oba woluminy akt czynności bpa Zamoyskiego były oprawione w pergamin. Współcześnie są natomiast oprawione w płótno, odpowiednio granatowe i szare.

Pod sygnaturą Rep 60 A 112 znajduje się w zbiorach Archiwum Archidiecezjalnego Lubelskiego niewielka księga dokumentująca czynności bpa Remigiusza Koniecpolskiego, zawierająca wpisy z 1633 r. od 29 kwietnia do 20 maja. Wydaje się zatem, że jest to część wspomnianej wyżej wkładki, która w 1743 r. dołączona była do akt bpa Zamoyskiego. Księga jest oprawiona w papier malowany z grzbietem z szarego płótna lnianego.

Odnotowana w regestrze pod numerem 3 księga wizytacji biskupich Jerzego Zamoyskiego i Remigiusza Koniecpolskiego znajduje się obecnie w archiwum 
pod sygnaturą Rep 60 A 149. Wydaje się, że jej współczesna zawartość, ujęta także w postaci spisu treści sporządzonego przez kanonika Balickiego w 1734 r., odpowiada stanowi sprzed dwóch i pół wieku. Księga ma oprawę z lnianego, szarego płótna. Niegdyś oprawiona była w biały pergamin.

Księga pod numerem $4 \mathrm{w}$ regestrze kanonika Balickiego oznaczona jest aktualnie sygnaturą Rep 60 A 108. Są to akta czynności biskupa chełmskiego Macieja Łubieńskiego, sprawującego swój urząd w latach 1621-1627. Aktualny zakres chronologiczny wpisów księgi pokrywa się z podanym w regestrze z $1743 \mathrm{r}$. Na końcu księgi znajduje się natomiast niedatowany i niepodpisany wykaz jej zawartości. Księga oprawiona niegdyś w zielony pergamin obecnie jest oprawiona w szare płótno lniane.

Księga pod numerem $6 \mathrm{w}$ regestrze kanonika Balickiego, zachowana jest obecnie pod sygnaturą Rep 60 A 109. Są to akta konsystorza z okresu sprawowania funkcji oficjała przez Jana Abrahama Śladkowskiego, sufragana chełmskiego, a następnie akta czynności tegoż, jako administratora sede vacante. Daty z regestru z 1743 r. niemal zupełnie pokrywają się z obecną zawartością księgi, przy czym ostatni wpis pochodzi z dnia 18 nie zaś z 17 marca 1641 r., co zapewne było pomyłką sporządzającego regestr. Warto jednak wspomnieć, że acta officialia kończą się 25 września 1628 r., po czym od 22 listopada 1640 r. rozpoczynają się acta administratorialia. Księga jest oprawiona w szare płótno lniane, niegdyś natomiast miała żółtą oprawę pergaminową.

Księga numer 7 oznaczona jest obecnie sygnaturą Rep 60 A 110. Jest to księga konsystorska z okresu sprawowania funkcji oficjała przez kanonika chełmskiego Jana Sasina. Daty z regestru odpowiadają w zupełności współczesnej zawartości księgi. Warto zauważyć, że dołączony jest do niej spis treści, wykonany przez kanonika Balickiego i datowany przez niego 11 czerwca 1734 r. w Skierbieszowie. Księga jest oprawiona w szare płótno lniane, niegdyś była oprawiona w szarą skórę.

Kolejna księga regestru, zapisana pod numerem 8, oznaczona jest obecnie sygnaturą Rep 60 A 111. Są to akta konsystorskie z okresu oficjalatu kanonika chełmskiego Jana Sasina. Informacja z 1743 r. w pełni odpowiada zakresowi chronologicznemu zapisanych tam czynności. Do księgi dołączony jest indeks alfabetyczny, bez informacji o dacie jego powstania i autorstwie. Niegdyś księga była oprawiona w szarą skórę, obecnie zaś w szare płótno lniane.

Księga wpisana w regestrze pod numerem 9 jest przechowywana $\mathrm{w}$ archiwum pod sygnaturą Rep 60 A 114. Jest to księga z wpisami z czasów administratora sede vacante, sufragana chełmskiego Jana Abrahama Śladkowskiego, kolejnego sufragana i oficjała chełmskiego Mikołaja Świrskiego, a także sędziego surogata, kanonika Franciszka Malinowskiego. Obejmuje odpowiednio wpisy od 23 marca 1641 r. do 3 października 1641 r., od 1 lutego 1651 r. do 8 marca 1652 r. oraz przemieszane wpisy czynności wykonanych bądź przez bpa Świrskiego bądź przez surogata Malinowskiego w 1653 r. Księga oprawiona jest w szare płótno lniane, niegdyś natomiast miała oprawę pergaminową w kolorze białym.

Odnotowana w regestrze pod numerem 10 księga wizytacji biskupiej Remigiusza Koniecpolskiego, przeprowadzonej przez kanonika Jana Sasina w latach 
1635-1638, znajduje się aktualnie w archiwum pod sygnaturą Rep 60 A 150. Jej zawartość w ciągu wieków nie uległa zmianie. Obecna oprawa jest płócienna, Iniana, szara. Niegdyś wolumin miał białą oprawę pergaminową.

Księga wpisana w regestrze pod numerem 11 ma w archiwum sygnaturę Rep 60 A 113. Jest to księga czynności biskupich dwóch kolejnych pasterzy chełmskich - Pawła Piaseckiego i Stanisława Pstrokońskiego, pełniących posługę biskupią odpowiednio w latach 1641-1644 i 1644-1657. Informacja z regestru dotycząca zasięgu czasowego wpisów w pełni odpowiada aktualnemu stanowi księgi. Do woluminu dołączony jest natomiast spis zawartości, sporządzony przez kanonika Balickiego w $1734 \mathrm{r}$. Księga jest oprawiona w szare płótno lniane, niegdyś miała oprawę skórzaną koloru szarego.

Pozycja $12 \mathrm{w}$ regestrze kanonika Balickiego znajduje się w aktualnych zasobach archiwum i jest oznaczona sygnaturą Rep 60 A 115. Księga, zgodnie z informacją z regestru, zaczyna się wpisem z 27 maja 1646 r., natomiast kończy wpisem z 8 lutego $1651 \mathrm{r}$. Stąd też przypisanie całości księgi okresowi oficjalatu bpa Mikołaja Swirskiego jest mylne. W księdze znajduje się bowiem, poczynając od 23 marca 1650 r., ciąg wpisów za oficjalatu Krzysztofa Bąkowskiego, następnie acta administratorialia bpa Mikołaja Świrskiego, a także akta czynności Baltazara Golańskiego, sędziego surogata. Do księgi dołączony jest spis jej zawartości, wykonany w 1734 r. przez kanonika Balickiego. Księga jest oprawiona w szare płótno lniane, niegdyś natomiast miała oprawę pergaminową.

Pod numerem $13 \mathrm{w}$ regestrze została odnotowana księga zamojskiego oficjalatu foralnego, na którego czele stał kanonik Andrzej Kłopocki. W obecnym układzie zbiorów archiwalnych została ona opatrzona sygnaturą Rep 60 A 147. Zakres czasowy wpisów do tej księgi odpowiada w zupełności informacji zawartej w regestrze. Do woluminu został dołączony spis jego zawartości, sporządzony w 1734 r. przez kanonika Balickiego. Aktualnie księga ma oprawę z szarego płótna lnianego. Według regestru oprawiona była w papier marmurkowy.

Księga odnotowana w regestrze pod numerem 14 otrzymała w obecnym archiwum sygnaturę Rep 60 A 151. Zgodnie z informacją z regestru zawierała ona zarówno akta czynności biskupich Krzysztofa Żegockiego, biskupa chełmskiego w latach 1670-1673, jak też akta wizytacji przeprowadzonej przez tegoż biskupa. Także w aktualnym kształcie księga zawiera wspomniane acta episcopalia z lat 1670-1671, jak również acta visitationis z lat 1671-1672. Do woluminu został dołączony alfabetyczny indeks zawartości. Księga jest oprawiona w szare płótno lniane. Niegdyś miała oprawę szarą, ale skórzaną.

Zanotowany w regestrze pod numerem 15 brudnopis akt oficjalatu chełmskiego z lat 1685-1687 stanowi obecnie część księgi oznaczonej sygnaturą Rep 60A 116. Znajdują się w niej bowiem także wcześniejsze wpisy z lat 1677-1680, ale również wpisy z lat 1692-1696, które wydają się odpowiadać pozycji numer $17 \mathrm{w}$ regestrze sporządzonym przez kanonika Balickiego. Księga jest oprawiona w szare płótno lniane. Pozycja 15 regestru oprawiona była niegdyś w papier nakrapiany. Natomiast pozycja 17 nie była szyta i oprawiona, ale pozostawała w tece z szarej skóry.

Księga zapisana w regestrze pod numerem 16 znajduje się w archiwum opa- 
trzona sygnaturą Rep 60 A 118. Są to akta czynności biskupich Stanisława Jacka Święcickiego, biskupa chełmskiego w latach 1677-1696. Wpisy datują się od 26 sierpnia 1686 r. do 9 grudnia 1691 r., a zatem różnią się niewiele od ram zakreślonych w regestrze kanonika Balickiego. Na końcu księgi znajduje się niedatowany spis zawartości. Wolumin jest oprawiony w szare płótno lniane. W czasie sporządzania regestu księga była oprawiona w szarą skórę.

Pod numerem 18 w regestrze występuje protokół akt administratora diecezji chełmskiej bpa Jana Dłużewskiego. Księga ta w obecnym układzie archiwum oznaczona jest sygnaturą Rep 60 A 119. Daty wpisów przywołane w regestrze zgadzają się w zupełności z obecną zawartością księgi. Wolumin ma oprawę z szarego płótna lnianego, niegdyś natomiast był wszyty w pergamin.

Pozycja 19 w regestrze z 1743 r. to acta administratorialia z czasów Pawła Choteckiego, archidiakona w kapitule chełmskiej. Księga ma charakter brudnopisu, oznaczona jest obecnie sygnaturą Rep 60 A 120 i obejmuje wpisy z okresu od 26 sierpnia 1705 r. do 13 lutego 1713 r. Odbiega zatem nieznacznie od ram wskazanych w regestrze. Różni się także oprawą, która niegdyś była pergaminowa, obecnie zaś jest płócienna z szarego materiału lnianego.

Kolejna pozycja w regestrze, zanotowana pod numerem 20, oznaczona jest w archiwum sygnaturą Rep 60 A 121. Zachodzą tu jednak pewne drobne różnice. Poza wskazanymi w regestrze brudnopisami akt oficjalskich Walentego Czulskiego, które rozpoczynają się wpisem z 23 marca 1713 r. i biegną z przerwami do 6 września 1719 r., jak również brudnopisami akt biskupa Krzysztofa Jana Szembeka, notowanymi od 27 sierpnia 1714 r. do 9 czerwca 1719 r., w woluminie został umieszczony niewielki fragment brudnopisu akt biskupich Aleksandra Fredry, obejmujący okres od 20 września 1719 r. do 11 października 1719 r. Księga oprawiona jest $\mathrm{w}$ szare płótno lniane, niegdyś była wszyta w pergamin.

Oznaczone w regestrze numerami 21 i 22 księgi wizytacji biskupiej Krzysztofa Jana Szembeka, biskupa chełmskiego w latach 1713-1719, także dziś stanowią dwie kolejne pozycje archiwalne pod sygnaturami Rep 60 A 152 i Rep 60 A 153. Ich zawartość zgadza się z treścią wymienioną przez autora regestru. Zakres chronologiczny pierwszego tomu to lata $1714-1718$, natomiast w drugim tomie występują materiały z lat 1712-1718. Księgi mają częściowe spisy treści. Warto dodać, że mylące w pewnym sensie mogą być określenia, mówiące o tomie większym i mniejszym. Choć formalnie wskazówka ta jest poprawna, to w rzeczywistości są to jedne z najobszerniejszych tomów wśród archiwaliów odziedziczonych po niegdysiejszej łacińskiej diecezji chełmskiej. Liczą bowiem odpowiednio 1014 i 629 kart. Według regestru księgi te były oprawione w szarą skórę. Obecnie pierwszy z woluminów ma oprawę z szarego płótna lnianego, drugi natomiast jest oprawiony w malowany papier.

Księga wymieniona w regestrze pod numerem 24 jest przechowywana w archiwum pod sygnaturą Rep 60 A 122 . Zawiera brudnopis akt oficjalskich Walentego Czulskiego z okresu od 19 lutego 1721 r. do 7 listopada 1724 r. Następnie w księdze znajduje się czystopis akt sędziego delegowanego Franciszka Ksawerego Kunickiego z okresu od 5 maja do 3 listopada 1724 r. oraz acta administratorialia Michała Delamars i acta officialia Franciszka Ksawerego Kunickiego 
z okresu sediswakancji, w czystopisie, obejmujące wpisy od 10 listopada $1724 \mathrm{r}$. do 24 stycznia $1725 \mathrm{r}$. W regestrze podano zatem błędnie daty roczne, które w samej księdze były wyraźnie poprawiane. Warto dodać, że akta te, które pozostawały w luźnych seksternach w archiwum kapitulnym, złożył w całość kanonik Balicki w 1738 r., jak o tym napisał na tytułowej karcie księgi. Aktualnie całość jest oprawiona w szare płótno lniane, niegdyś była oprawiona w szarą skórę.

Księga pod numerem $25 \mathrm{w}$ regestrze jest aktualnie oznaczona $\mathrm{w}$ archiwum sygnaturą Rep 60 A 123. Rozpoczyna się spisem treści sporządzonym bez wątpienia ręką kanonika Balickiego. Jej zawartość niemal w pełni odpowiada opisowi regestru, a więc obejmuje akta sądowe Jana Feliksa Szaniawskiego, biskupa chełmskiego $\mathrm{z}$ lat 1725-1733, przy czym wpisy rozpoczynają się 16 kwietnia $1725 \mathrm{r}$. a kończą 17 grudnia 1727 r. Ponadto do księgi dołączone zostało świadectwo uprawnień notarialnych chełmskiego kanonika honorowego, Walentego Wróblowskiego. Księga została oprawiona w szare płótno lniane.

Pod numerem $27 \mathrm{w}$ regestrze kanonika Balickiego wymieniona została księga, która obecnie w archiwum oznaczona jest sygnaturą Rep 60 A 124. Aktualnie zawiera ona spis części zawartości, następnie acta iudiciaria bpa Jana Feliksa Szaniawskiego z okresu od 5 stycznia 1731 r. do 12 kwietnia 1732 r. Ponadto w tej samej księdze znajduje się zapisany osobno w regestrze pod numerem 29 brudnopis akt sądowych bpa Szaniawskiego, obejmujący wpisy od 14 marca 1731 r. do 4 listopada 1733 r. Księga jest oprawiona w szare płótno lniane.

Oznaczona numerem 30 w regestrze księga wizytacji biskupich Jana Feliksa Szaniawskiego znajduje się aktualnie w archiwum pod sygnaturą Rep 60 A 154. Wolumin zawiera dołączony na końcu spis parafii zwizytowanych, ułożony w porządku dekanatów. Daty wspomniane w regestrze odpowiadają zawartości księgi, aczkolwiek karty nie są ułożone w porządku chronologii wpisów. Wolumin jest oprawiony w szare, lniane płótno.

Księga wymieniona pod numerem $31 \mathrm{w}$ regestrze aktualnie oznaczona jest sygnaturą Rep 60 A 125. Zawiera ona akta oficjała delegowanego Wawrzyńca Czulskiego z okresu sediswakancji, z czasów administratury Walentego Chlebowskiego i Aleksandra Grzymały, wraz z ich aktami czynności. Akta Czulskiego w czystopisie datują się od 8 stycznia do 7 września 1734 r. Następnie w tej samej księdze występuje brudnopis akt oficjalskich od 15 września 1734 r. do 20 grudnia 1736 r. oraz analogiczne brudnopisy czynności wymienionych administratorów. Na początku księgi umieszczono niepełny spis treści, obejmujący lata 17341735. Księga jest oprawiona w szare płótno lniane.

Kolejna księga w regestrze, zapisana pod numerem 32, wydaje się znajdować aktualnie w archiwum w dwóch następujących po sobie woluminach, przy czym są to księgi zawierające brudnopisy. Oznaczone są one sygnaturami Rep 60 A 126 i Rep 60 A 127. Są to protokoły sędziów delegowanych przez biskupa Józefa Eustachego Szembeka, pasterza chełmskiego w latach 1736-1753. Obejmują one odpowiednio wpisy z następujących okresów: 10 kwietnia do 13 grudnia $1737 \mathrm{r}$. oraz 7 stycznia do 19 września 1738 r. Jednakże drugi z woluminów zawiera również pojedyncze wpisy późniejsze, sięgające aż do 16 lutego 1743 r. Każda z ksiąg oprawiona jest w szare płótno lniane. 
Księga wizytacji odnotowana pod numerem $33 \mathrm{w}$ regestrze kanonika Balickiego znajduje się w archiwum pod sygnaturą Rep 60 A 156. Księga ta zawiera opisy status ecclesiarum z lat 1740-1742 wraz z dekretami reformacyjnymi wydanymi przez bpa Józefa Eustachego Szembeka. Na początku księgi znajduje się alfabetyczny indeks parafii ujętych $\mathrm{w}$ tym woluminie. Księga jest oprawiona w szare płótno lniane.

Wydaje się, że wymienione pod numerami 34 i 35 w regestrze kanonika Balickiego luźne papiery, nie znajdują się obecnie w Archiwum Archidiecezjalnym Lubelskim. Zresztą ich ogólny opis czyniłby je trudnymi do zidentyfikowania. Należy wątpić, aby chodziło w tym wypadku o luźne materiały, które znajdują się w tekach oznaczonych sygnaturami Rep 64 T 6 oraz Rep 64 T 8. Teki te zawierają co prawda materiały odpowiednio z lat 1680-1699 oraz 1720-1739, ale są to dokumenty odzwierciedlające zasadniczo aktywność kapitulną, a nie konsystorską.

\section{Wnioski}

Ustalenia poczynione w wyniku analizy porównawczej wykazu akt biskupich i konsystorskich przekazanych w 1743 r. do archiwum kapitulnego przy katedrze w Krasnymstawie oraz materiałów przechowywanych aktualnie w Archiwum Archidiecezjalnym Lubelskim prowadzą do kilku wniosków ogólniejszej natury. Pozytywnym zaskoczeniem jest bardzo wysoki stopien zachowania omawianych materiałów. Spośród trzydziestu pięciu pozycji wymienionych w regestrze kanonika Balickiego jedynie sześciu brakuje w dzisiejszych zasobach archiwum, co daje powód do postawienia tezy o kompetentnym obchodzeniu się archiwariuszy z powierzonymi im materiałami i to pomimo gwałtownych przemian instytucjonalnych i ze wszech miar niekorzystnych okoliczności dziejowych. Zaginione woluminy występują w regestrze pod numerami 5, 23, 26, 28, 34 i 35.

W niektórych wypadkach zawartość ksiąg uległa przesunięciu, choć na ogół cechowały się one stałością. Tylko w niewielkim stopniu księgi wykazują rozbieżność chronologiczną w stosunku do ich opisu w regestrze. Możliwe jednak, że różnice te wynikają nie tyle z materialnych strat, co z pobieżnego oglądu i w konsekwencji omyłkowego omówienia dokonanego onegdaj przez autora regestru.

Zdecydowane różnice występują w zewnętrznym wyglądzie ksiąg, a mianowicie w oprawach woluminów. Trudno ocenić czy skórzane oprawy sprzed ponad dwóch i pół wieku po prostu się zużyły i wymagały całkowitej zmiany, czy też raczej zostały z premedytacją oddzielone $\mathrm{z}$ innych powodów.

Warto na koniec zauważyć, że księgi przekazane w 1743 r. do archiwum kapitulnego - być może nawet wbrew przekonaniu sporządzającego regestr kanonika Balickiego - nie były kompletem istniejących wówczas akt biskupich i konsystorskich. Świadczy o tym znajdująca się obecnie w Archiwum Archidiecezjalnym Lubelskim księga oznaczona sygnaturą Rep 60 A 117. Są to akta sądowe bpa Stanisława Jacka Swięcickiego i akta oficjalskie Jana Konstantego Wożuczyńskiego. Pomimo że księga datuje się z 1679 r., to jednak nie ma jej w regestrze kanonika Balickiego, choć niewątpliwie musiała istnieć. Trafiła zatem do archiwum w innym czasie.

słowa kluczowe: rzymskokatolicka diecezja chełmska, archiwum, archidecezja lubelska, konsystorz chełmski 


\title{
HERI ET HODIE. \\ BISHOPRIC AND CONSISTORY RECORDS OF CHEŁM ACCORDING TO THE DELIVERY AND ACCEPTANCE PROTOCOL OF 1743 AND THEIR CURRENT CONDITION IN THE ARCHDIOCESAN ARCHIVE OF LUBLIN
}

\begin{abstract}
Summary
In 1743 Canon Józef Ludwik Balicki drew up an inventory of the documents transferred to the Archive of the Cathedral Chapter in Krasnystaw. Those materials came from the office of the bishops of Chełm and the Consistory of Chełm. The inventory has been published in the following article. Are the materials listed in the inventory in the folds of the Archdiocesan Archives of Lublin now? And to what extent have they been preserved? The findings, done on the basis of the comparative analysis, lead to several conclusions of a more general nature. A positive surprise is the fact that most of those materials have been preserved. Of the thirty-five items listed in Canon Balicki's inventory only six are missing in today's records of the archive. It enables the author to propose a theory of competent handling the entrusted materials, in spite of the rapid institutional changes and the adverse circumstances in history. There are only little chronological discrepancies in the books in relation to their description in the register. It is possible that these differences arise not so much from the material losses, but from a cursory inspection and consequently wrong description of the material once done by its author. Distinct differences exist, however, in the external appearance of the books, namely the binding of the volumes.
\end{abstract}

Keywords: Roman Catholic Diocese of Chełm, archive, Archdiocese of Lublin, Consistory of Chełm 